\title{
Learning from the history of disaster vulnerability and resilience research and practice for climate change
}

\author{
I. Kelman ${ }^{1,2} \cdot$ J. C. Gaillard ${ }^{3} \cdot$ James Lewis $^{4}$ • \\ Jessica Mercer 5
}

Received: 8 June 2015/ Accepted: 16 November 2015/Published online: 21 March 2016

(C) The Author(s) 2016. This article is published with open access at Springerlink.com

\begin{abstract}
Humanity has long sought to explain and understand why environmental processes and phenomena contribute to and interfere with development processes, frequently through the terms and concepts of 'vulnerability' and 'resilience'. Many proven ideas and approaches from development and disaster risk reduction literature are not fully considered by contemporary climate change work. This chapter describes the importance of older vulnerability and resilience research for contemporary investigations involving climate change, suggesting ways forward without disciplinary blinkers. Vulnerability and resilience as processes are explored alongside critiques of the post-disaster 'return to normal' paradigm. The importance of learning from already existing literature and experience is demonstrated for ensuring that complete vulnerability and resilience processes are accounted for by placing climate change within other contemporary development concerns.
\end{abstract}

Keywords Climate change $\cdot$ Disasters $\cdot$ Development $\cdot$ History $\cdot$ Resilience Vulnerability

I. Kelman

ilan_kelman@hotmail.com

1 Institute for Risk and Disaster Reduction and Institute for Global Health, University College London, Wilkins Building - South Wing, Gower Street, London WC1E 6BT, UK

2 Norwegian Institute for International Affairs (NUPI), C.J. Hambros Plass 2D, PB 8159 Dep, 0033 Oslo, Norway

3 School of Environment, The University of Auckland, Private Bag 92019, Auckland 1142, New Zealand

4 Datum International, 101, High Street, Marshfield, South Gloucestershire, Chippenham SN14 8LT, UK

54 St. Johns Road, Winchester, Hampshire SO23 OHQ, UK 


\section{Introduction}

Humanity has long sought to explain and understand why environmental processes and phenomena contribute to and interfere with development and livelihoods processes including health, energy, food, and water. In considering modern scientific thought and method, the terms 'vulnerability' and 'resilience' are frequently employed, especially for examining disasters through a development lens. The mid-1970s to the mid-1980s, in particular, witnessed formal intersection of the long literature of disaster studies (e.g. Carr 1932; Prince 1920; White 1936, 1937) with ongoing work in international development in order to examine and develop the concepts of vulnerability and resilience (Ball 1975; Comité d'Information Sahel 1975; Copans 1975; O'Keefe et al. 1976; Timmerman 1981; Tiranti 1977).

These studies demonstrated the importance of human actions, rather than environmental phenomena, as the fundamental causes of disasters. This work from two generations ago has never been overturned or undermined by subsequent examination. It has, though, often been bypassed to a large extent by more recent research into the contemporary challenge of climate change caused, in part, by human activity. This chapter describes the importance of older vulnerability and resilience research for contemporary investigations involving climate change, suggesting ways forward without disciplinary blinkers. The importance is learning from and applying recent history on vulnerability and resilience for dealing with climate change amongst other development challenges.

\section{Hazard, vulnerability, and resilience}

Disasters, by definition, occur due to a combination of hazard and vulnerability. For socalled natural disasters, hazard refers to the input from the environment, such as volcanic activity, precipitation or lack thereof, a microbial pathogen, or climatic trends. Most hazards regularly occur and are often necessary for society and the environment. For instance, volcanoes contribute to soil biogeochemistry (Crow et al. 2015) while precipitation including from storms feeds freshwater (Cashman 2014).

Vulnerability refers to the propensity to be harmed, in this case by a hazard, and to be unable to deal with that harm alongside the social processes creating and maintaining that propensity. Vulnerability encompasses human decisions, values, governance, attitudes, and behaviour forming situations in which hazards could potentially cause harm. Harm might be casualties, social and business interruption, and property damage.

Measures to tackle vulnerability could be technical, such as indoor climate control to avoid freezing or overheating during temperature extremes. Measures to tackle vulnerability are more often social. Examples are resource allocation to make one's own choices regarding vulnerability and political systems giving people options for holding leaders accountable when vulnerability reduction measures are not enacted. Most often, social and technical vulnerability reduction measures are intertwined, because social conditions permit which technical measures to be implemented and their effectiveness.

Building codes illustrate. The technical dimension of writing a building code for various materials and construction techniques in which structures will not collapse in high-magnitude, shallow earthquakes involves long-established knowledge. The social tasks of promulgating, monitoring, and enforcing a building code with these provisions, alongside providing adequate training opportunities and accountability for design professionals, takes 
much longer and requires many more resources (Bosher 2008; Lewis 2003; Spence 2004). These tasks are part of development processes linked to education, governance, and social services, and they have not been fully solved.

Consequently, development decisions creating and perpetuating vulnerability are the root causes of disasters, not environmental phenomena which sometimes become hazardous. From this vulnerability viewpoint, disasters are not 'natural', neither in the sense of being from nature nor in the sense of being normal and acceptable. The focus on human actions, behaviour, decisions, attitudes, and values leading to vulnerabilities which cause disasters, with the implication that disasters are not 'natural', is now embedded in the disaster-related development literature (e.g. Hewitt 1997; Lewis 1999; Mileti et al. 1999; Oliver-Smith 1986; Steinberg 2000; Wisner et al. 2004). It is also accepted by development policy makers and practitioners (e.g. Global Network of Civil Society Organisations for Disaster Reduction 2009, 2011; Turcios 2001; UNISDR 2002).

The choices and processes of ensuring that society can deal with hazards and hazard drivers are usually termed 'building resilience'. From the previous examples, resilience could be effected through engineering appropriate seismic resistance techniques and creating the social structures to implement, monitor, and enforce them (e.g. Coburn and Spence 2002; Lewis 2003). As with volcanic ash, slow-rise floods can enrich soil for agriculture, so building resilience means pursuing livelihoods due to regular flooding rather than floods becoming flood disasters (e.g. Cuny 1991; Wohl 2000; Zaman 1993).

While resilience and vulnerability have some converse characteristics, they are not necessarily exact opposites since aspects of both can exist simultaneously. Each can be viewed as a separate concept and process overlapping with each other and with many other development concepts and processes. It is not straightforward to pin down or to develop an unambiguous and universally accepted relationship between the two, notably due to different definitions of vulnerability and resilience. Resilience, in particular, has diverse definitions and conceptualisations, often contradictory and often embedded within disciplines and bounded by a disciplinary mindset, including from ecology, engineering, and psychology (Alexander 2013).

Both terms can be nebulous. Not all languages have words for 'vulnerability' and 'resilience'. The contemporary English concepts are alien to many cultures including indigenous Pacific islanders and indigenous Arctic peoples (Kelman et al. 2011). In analysing vulnerability and resilience, care is needed to embrace ideas, literature, and approaches from a breadth of development work, rather than focusing on a narrow disciplinary analysis.

Adopting a broad, encompassing view entails recognizing that no conceptual model, including the conclusion that no disasters are natural, is absolute; exceptions and counterexamples exist. Asteroids or comets striking the Earth are not 'natural disasters' because affordable mechanisms exist to monitor and counter threats but resources have not been allocated to support them (Perna et al. 2015). Conversely, basaltic floods (Courtillot and Fluteau 2014), ice ages (Martin 2005), and gamma-ray flares from nearby stars (Palmer et al. 2005) would be difficult for humanity to counter or to avoid a planet-wide calamity.

Aside from these low-probability, high-consequent exceptions, many environmental events and processes are not necessarily hazardous, for two reasons. First, at times, the creation of vulnerability also creates a hazard. Cold weather in the U.K. is usual in winter and many have long survived it without trouble. When inequity leads to people living in inadequate accommodation without being able to afford heating, the result can be 3500 excess winter deaths per year per degree lower of average temperature after adjusting for flu and age (Laake and Sverre 1996). Given that the homes have heating systems, but the 
tenants cannot afford the cost, the cold becomes a hazard only because vulnerability exists in the form of inequity and poverty. Second, as already discussed, many environmental events and processes are resources. Slow-rise river floods can deposit nutrients leading people to settle in floodplains to farm the land (Cuny 1991; Wohl 2000; Zaman 1993), while seismic zones can increase groundwater accessibility encouraging settlements to develop across earthquake faults (Jackson 2001).

\section{Vulnerability and resilience in climate change research}

Human emissions into the atmosphere affecting the global climate have been postulated since at least the nineteenth century with Arrhenius (1896) being one of the suggestion's later expressions. Twentieth century summaries (see also Weart 2008) include Revelle and Suess (1957) and MIT $(1970,1971)$ leading to the founding of the Intergovernmental Panel on Climate Change (IPCC), a United Nations body.

The IPCC's mandate is to assess scientific literature on climate change and potentialassociated consequences. IPCC's work is not original science, nor is it meant to be, since the IPCC's mandate is to synthesize existing science as reviewed and accepted by member state governments. Governments comment on and then adopt IPCC reports, signifying the IPCC's valuable role in developing a governmental consensus on the state of climate change science. The first IPCC assessment was in 1990 while the most recent one is the Fifth Assessment Report (IPCC 2013-2014). In between, the IPCC has issued other reports to indicate climate change perspectives on topics such as disaster risk reduction (IPCC 2012), although that report does not account for the full gamut of disaster risk reduction research such as on vulnerability and resilience.

\subsection{Narrower perspectives on vulnerability and resilience}

IPCC (2013-2014, p. 28) defines vulnerability to be 'The propensity or predisposition to be adversely affected. Vulnerability encompasses a variety of concepts including sensitivity or susceptibility to harm and lack of capacity to cope and adapt'. Several other terms require definitions - 'sensitivity', 'cope', and 'adapt' — which are defined by IPCC (20132014), always within the climate change context. For example, 'sensitivity' is defined as 'The degree to which a system or species is affected, either adversely or beneficially, by climate variability or change'. The effect may be direct (e.g. a change in crop yield in response to a change in the mean, range, or variability of temperature) or indirect (e.g. damages caused by an increase in the frequency of coastal flooding due to sea-level rise)' (IPCC 2013-2014, p. 24). As such, 'vulnerability' applies for climate change, which is suitable for IPCC purposes including for IPCC (2012), but which does not embrace the full range of literature available or connect climate change to other contexts, even when those contexts apply similar concepts (e.g. Papathoma-Koehle et al. 2011).

IPCC's (2013-2014, p. 23) definition of resilience is 'The capacity of a social-ecological system to cope with a hazardous event or disturbance, responding or reorganizing in ways that maintain its essential function, identity, and structure, while also maintaining the capacity for adaptation, learning, and transformation'. Numerous other definitions are required, along with the clear bias in vocabulary from ecology, such as 'disturbance' (Townsend et al. 2003). A possible contradiction emerges in desiring the maintenance of 'its essential function' alongside 'the capacity for' different forms of change. Yet, no 
explanation is given why essential functions should be immune to change for a society continually seeking to overcome ills such as discrimination and rights violations.

In particular, observations and analyses of ecosystems from ecological perspectives are from a deliberately removed external viewpoint. The assumptions used to be that an ecosystem is an entity observed externally and that it can be analysed as such. In disaster risk reduction and development, ecological processes are not assumed to be benign or neutral, but can help or hinder development endeavours. Within that context, vulnerability and resilience are societal concerns about impacts upon ourselves, others, and the environment (see also, amongst many, Pugh 2014; Sudmeier-Rieux 2014; Weichselgartner 2001). The history and root causes from which vulnerability and resilience emerge have always been of concern in disaster-related development work, aiming to understand why a system can or cannot 'cope with a hazardous event or disturbance' - the reasons of which are often due to 'its essential function, identity, and structure' supporting vulnerability and hindering resilience.

Despite such critiques of the IPCC approach based on the alternatives provided through the long history of literature cited in this chapter, the IPCC approach continues to infiltrate policy. IPCC (2012), for instance, did not fully account for analyses of the IPCC's earlier definitions (e.g. Lewis and Kelman 2010). Policy institutions such as UNISDR (2015) and ODI (2015) explicitly use the ecosystem ethos of resilience, in terms of returning to what existed before, without explaining why the interdisciplinary views are seemingly unacceptable to them.

Why is IPCC work on vulnerability and resilience so focused and not fully accounting for wider perspectives? Adger (2006) and Folke (2006) tend to be seen as the key papers on vulnerability and resilience, respectively, epitomizing the IPCC's theoretical baseline and feeding into the Fourth Assessment in 2007, significant elements of which remain in the Fifth Assessment. Adger (2006, p. 268) states 'The purpose of this article is to review existing knowledge on analytical approaches to vulnerability to environmental change in order to propose synergies between research on vulnerability and on resilience of socialecological systems'. Folke (2006, p. 254) states 'The purpose with this paper is to provide an overview of the emergence of the resilience perspective and the context within which it has developed'. Consequently, it seems reasonable to expect that these papers provide an adequate literature review of the topic.

Samples of key vulnerability and resilience works viewing disaster risk reduction as a development process which are not mentioned by Adger (2006) or Folke (2006) are Waddell (1977), Torry (1979), Oliver-Smith (1979, 1986), Maskrey (1989), Lewis (1979, 1988, 1999, 2003), Lavell (2000), Garcia-Acosta (2004), Hoffman and Oliver-Smith (2002), Glantz (1994a, b), Enarson and Morrow (1998) and Copans (1975). Is this criticism legitimate or overthe-top? Perfectly fairly, no publication can cover all literature. Just as this chapter makes no claim of being comprehensive and could not be comprehensive, there is no expectation that the dominant climate change literature would or could cover all authors who have ever published on the topics. Achieving that task would be impossible, especially in a length-limited paper. As such, the dominant climate change literature could explicitly acknowledge and explain that it intentionally overlooks earlier work from disaster and development studies. A major consequence of the oversight is conceptual limitations in vulnerability and resilience as understood through a climate change lens, reflected in discussion in IPCC (2012) and remaining present in IPCC's (2013-2014) definitions (as provided above).

Two illustrative examples are given from Adger (2006). First, Adger (2006, p. 276) states 'Vulnerability is manifest in specific places at specific times'. Disaster risk reduction embraces vulnerability's and resilience's manifestation as processes (see the next section) spanning time and involving place-based characteristics which must be balanced with non- 
place-based characteristics. Gaillard (2010) and Lewis and Kelman (2010) summarize pre2006 perspectives and citations regarding these points which are not mentioned in Adger (2006). Second, Adger (2006, p. 276) writes 'A second challenge arises from the tension between objective and perceived elements of vulnerability and risk.' This quotation appears to assume that vulnerability and risk have objective elements. A large, long-standing body of work from disaster risk reduction (e.g. Bankoff et al. 2004; Hewitt 1983, 1997; Lewis 1999; Oliver-Smith 1986; Wisner et al. 2004) has shown theoretically and empirically that vulnerability and risk are contextual and subjective-a notion which has also long been accepted as a tenet in many social science disciplines (see also Adams 1999).

Meanwhile, Folke (2006, p. 262) raises similar questions with an illustrative quotation stating 'A vulnerable social-ecological system has lost resilience. Losing resilience implies loss of adaptability'. Perspectives from the pre-2006 citations provided throughout this chapter, embracing disaster risk reduction as a development process, provide much more nuanced approaches and understandings regarding the relationships amongst 'vulnerability', 'resilience', and 'adaptability'. Folke (2006) does well in funnelling ecosystem science views. Disaster risk reduction and development, of which climate change is an important component, deal with societies as well as ecosystems.

When analyses of vulnerability and resilience are conducted using the IPCC's perspective, conclusions result that could be challenged based on development literature. Janssen et al. (2006) set out 'to objectively identify major research topics, experts, papers, etc., in the three knowledge domains of interest' (p. 241) which are vulnerability, resilience, and adaptation. They also do not cite substantial portions of development literature, including many of the authors listed above. It is unclear why Janssen et al. (2006) highlight that 'Liverman's (1990) work connected the term vulnerability to global environmental change' (p. 248) as an iconic step in science when, the year before, Lewis (1989) connected Tuvalu's vulnerability to the threat of sea-level rise emerging from global environmental change.

Overall, vulnerability and resilience from the IPCC's perspective would be legitimate if climate change were the only development concern facing humanity. Even if climate change were indeed the greatest global crisis that humanity has ever faced (e.g. King 2004), then other development concerns would still need to be addressed. As discussed later, solving climate change could exacerbate these other development concerns. The role that climate change plays should be recognized, but without avoiding the wide variety of other existing significant development challenges, from land tenure to gender equity to HIV/AIDS - all of which intersect with climate change (e.g. Gommes et al. 2004).

'Double exposure' exemplifies research focused on climate change contributing to the IPCC without fully accounting for other development topics. 'Double exposure' is constructed as referring to those having to deal with global environmental change and economic globalization together having their vulnerability increased due to the dual challenges (Leichenko and O'Brien 2008). The notion's premise is that the two processes of global environmental change and economic globalization are intimately connected. That statement is a truism. For instance, the two main causes of climate change, greenhouse gas emissions and lack of greenhouse gas sinks, emerge to a large degree (although not exclusively) due to globalization. In addition to increasing vulnerability, the authors argue that the interactions increase inequality and rates of change.

As described in the development citations given in this chapter (see also the background given by Kelman et al. 2015), vulnerability and resilience have been analysed theoretically and empirically to demonstrate 'multiple exposure' at multiple scales. Vulnerability to hazards such as earthquakes and vulnerability to hazard drivers such as climate change, alongside poverty, inequity, injustice, globalization, resource distribution, and lack of 
access to education and health opportunities - amongst many other development challenges - are linked to each other and tend to overlap to cause the most adverse impacts for those who have the fewest choices, resources, and abilities for addressing the challenges. The convergence occurs at multiple scales, sometimes being local such as a minority group forced to live in floodplain slums and sometimes being global such as international trade agreements undermining workers' rights and opportunities.

Consequently, with numerous exceptions, those most vulnerable to one challenge tend to be most vulnerable to other challenges and tend to be most vulnerable across all these challenges, simultaneously illustrating multiple exposures to multiple threats at multiple scales. Highlighting 'double exposure' and highlighting the global level bypasses the long history of development and disaster risk reduction research, especially the frameworks and conceptual models incorporating multiple aspects such as pressure-and-release (Wisner et al. 2004) and the vulnerability process (Lewis 1979, 1999). The phrase 'multiple stressors' appears in Leichenko and O'Brien (2008, p. 31), but not citations to the longstanding multiple exposure approaches in the literature.

The danger of focusing on only two global processes is the loss of sub-global contexts which sometimes dominate people's vulnerability. Vulnerability to Hurricane Katrina in the U.S.A. in 2005, one of the examples used by Leichenko and O'Brien (2008), has been discussed in terms of racism, identifying principally local and national issues with limited input from either global environmental change or economic globalization (Henkel et al. 2006). No claim is made by Henkel et al. (2006) that racism alone (or inevitably) caused the disaster, but the authors forcefully demonstrate that no discussion about Katrina is complete without analysing the role which racism did and did not play. Of similar importance is understanding the non-global factors leading to key players being in charge at the time. Michael Brown led the Federal Emergency Management Agency despite minimal emergency management experience, while Ray Nagin was mayor of New Orleans and was later convicted of fraud, bribery, and money laundering. Local and national power analyses, in which global environmental change or economic globalization is effectively absent, are needed in order to determine why such individuals were the decision-makers.

A focus on 'double exposure' misses aspects of racism and leadership, amongst other factors, which created the vulnerability leading to the disaster across four states, not just New Orleans. Globalization nonetheless played a role in New Orleans' vulnerability through its historical position as a trade hub and immigration entry point (Arnesen 1994). In parallel, the impacts of global environmental change on Katrina's impacts and New Orleans were negligible in contrast to local and regional environmental changes augmenting the city's exposure and vulnerability through anthropogenic land subsidence and degraded wetlands (Day et al. 2007) —one consequence of globalization. This complex array of interacting factors cannot be fully explored using the 'double exposure' framework, thereby missing key elements which could help to understand today's vulnerability and resilience of Miami and Hilton Head to similar storms. In sum, global environmental change had limited influence on New Orleans' construction, development, or vulnerability, while globalization had a major influence along with national and local factors, so 'double exposure' is inadequate for analysing the Hurricane Katrina disaster.

\subsection{Not fully accounting for the vulnerability and resilience processes}

In narrowing the focus on how vulnerability and resilience are viewed, IPCC-related work has not entirely factored in the development and disasters literature highlighting the longterm nature of vulnerability and resilience accruing or being eroded. This view highlights 
vulnerability and resilience as being not only the current state, but also the process by which that current state was reached and the direction in which the current state is heading (e.g. Bankoff 2004; Crush 1995; Hewitt 1983, 2007; Lewis 1999; Oliver-Smith 1986; Wisner et al. 2004).

The 'vulnerability process' refers to the values, ideas, behaviours, and actions that have led to characteristics such as fragility, weakness, exposure, and susceptibility and that could perpetuate or absolve these issues (Kelman et al. 2015; Lewis 1979, 1999; Lewis and Kelman 2010). Because disasters are not natural but require an input of vulnerability, disasters do not happen quickly (Lewis 1988), instead with vulnerability accruing over the long term through social processes such as politics, resource distribution, and inequity. To deal with this long-term situation, aspects including resistance, resilience (sometimes 'resiliency'), capacity, capability, strength, power, empowerment, and sustainability are necessarily addressed (see also, amongst many others, Bankoff 2004; Crush 1995; Gaillard 2007, 2010; Manyena 2006; Manyena and Gordon 2015; Mitrovic 2015; Paton and Johnston 2001, 2006; Sudmeier-Rieux 2014).

Processes of vulnerability are perpetrated in the actions and activities of others who are sometimes remote from and beyond the influence or control of those most affected. When people do affect their own vulnerability, it can occur due to a lack of awareness, lack of choice, or inappropriate decision-making. The root causes are embedded in development topics, with examples being limited livelihood options; restricted land use; external exploitation of people, places, and resources; and perpetuating poverty, lack of control, and oppression. These actions can lead to environmental changes such as deforestation. They can expose people to regular environmental phenomena and processes such as floods and earthquakes making them hazards. Without options and access to grow adequate crops, to maintain adequate livestock, or to access adequate employment, resources, or services, people and communities are made to become marginalized, disadvantaged, and exploited. That is, they are made to become increasingly vulnerable over a long-term process (e.g. Bankoff 2004; Gaillard 2010; Hewitt 1983).

These theoretical ideas and principles have been implemented in practice. Oliver-Smith (1979) referred to a 400-year earthquake in examining the 31 May 1970 earthquake and rock avalanche in Yungay, Peru, which killed several thousand people. The ' 400 years' is not the geological return period of the seismic or slide event. Instead, it refers to the fact that the root causes of the vulnerability, which were exposed during the event, took 400 years to build up-a long-term process. The vulnerability that caused the disaster can be traced back to the Spanish invasion incorporating factors such as demographic patterns, mistreatment of the local population and local knowledge, settlement locations, and livelihoods.

As another example, Etkin (1999) describes how relying on structural flood defences increases vulnerability over the long term in a process termed 'risk transference'. Structural defences including large dams stop smaller floods and permit people to live in floodplains while remaining relatively dry. As a result of this false sense of security, vulnerability to flooding increases over the long term (see also Fordham 1999). Structural defences can fail, potentially due to poor maintenance or potentially due to an event which exceeds or has different characteristics from the design flood. Then, the damage incurred by the flood is much greater than it would have been without the false sense of security imposed by the structural defences. Short-term flood risk has decreased, but long-term flood risk has increased. Risk is transferred into the future and augmented, hence the term 'risk transference'. Risk can also be transferred amongst locations, sub-populations, and topics (e.g. Graham and Weiner 1995), making it important to consider multiple challenges and multiple exposures when assessing and addressing vulnerability and resilience. 
Resilience, like vulnerability, is a long-term process. Where disasters do not happen, then the resilience process should be acknowledged as the 'disasters averted'. A return period for the resilience process should not exist, so that disasters continue not to happen.

With that rationale, were the 26 December 2004 Indian Ocean tsunamis that killed approximately 250,000 people across more than a dozen countries, 100- or 200-year events or more? Or has coastal vulnerability built up much faster than the century scale, so that the tsunamis were 10- or 30-year events irrespective of the earthquake and tsunami's geological return periods? In places where people were aware of the post-earthquake tsunami threat and reacted appropriately saving hundreds of lives, such as on the island of Simeulue, Indonesia (Gaillard et al. 2008; McAdoo et al. 2006), how long could such a resilience process last?

Similar questions need to be posed for climate change, considering its long-term nature and its driving of many hazards. Without considering vulnerability and resilience as processes, posing these questions is difficult.

\section{Moving forward}

\subsection{Avoiding a 'normal' state}

The approaches related to vulnerability and resilience that tout a 'normal' state of society imply, or explicitly state, that society should 'return to normal' or go 'back to normal' after a shock such as a disaster or, in ecosystem science terms, a disturbance. The latter is the approach underlying the Resilience Alliance's interest (e.g. Folke 2006) in a system with 'the capacity...to absorb disturbance and reorganize while undergoing change so as to still retain essentially the same function, structure, identity, and feedbacks', as stated on the Resilience Alliance's website. No explanation is given for why society should always 'retain essentially the same function, structure, identity, and feedbacks'. As alluded to earlier, overcoming racial segregation and giving women equal rights are based on overturning the standard functions, structures, identities, and feedbacks of society.

The assumption that society has a 'normal' state could be questioned, since society always changes. Is society ever on an even, steady trajectory that could be called 'stable', 'usual', or 'normal' over the long term? The assumption that society would not wish to, or should not, change is questionable, because there are fundamental aspects of society's controls, functions, and processes that have changed in the past and that should change in the future.

Glantz and Jamieson (2000) and Tobin (1999) discuss that if resilience involves a return to pre-disaster conditions, then it is simply a return to the conditions, including vulnerability, which led to a disaster in the first place. Vulnerability is the chronic, 'normal' condition related to poor development practices (Hewitt 1983; Lewis 1999). If an aim is return to that 'normal' of the vulnerability process, then the next disaster is created-and would look similar to the disaster which just happened. 'Return to normal' or 'back to normal' should perhaps not be part of addressing vulnerability and resilience.

Furthermore, it often occurs that disaster survivors' experiences shape them for the rest of their lives, responding emotionally and through actions based on the disaster experience. When it rains, many flood survivors become stressed (Tapsell et al. 2002), although that does not preclude 'recovery' which could mean re-developing routines and continuing with day-to-day life and livelihood activities without the flood or future flood possibilities controlling all reactions and decisions. Irrespective, the experience and emotions of being 
flooded might never, and perhaps never should, go away, especially since forgetting it as if it never happened could set the stage for a similar future situation. A post-disaster 'Return to normal' might be neither possible nor wanted (Hills 1998; Fordham 1998).

Rather than 'bouncing back', resilience could instead be represented by doing much better than 'back to normal'. The post-disaster development paradigm of 'Build Back Better' personifies that approach, notwithstanding the critiques (Kennedy et al. 2008) leading to suggestions of 'build forward better' (Murphy and Ricks 2013), 'bouncing forward' (Manyena et al. 2011), and 'build better now' from buildings and energy (e.g. Richman et al. 2007) but being used in disaster risk reduction policy discourses. An important element of doing better than 'normality' is restoring routines and day-to-day actions such as children going to school and cultural rituals. An anchor is provided within which a new 'normal' can be formed for the post-disaster environment, yet still accepting the hesitancy in aiming to restore entirely the pre-disaster state. Re-establishing beneficial practices, ensuring that everyday needs are fulfilled, and changing social processes and structures which sustain vulnerability would be the long-term resilience process preventing the next disaster from occurring - and the previous one from recurring.

Nonetheless, despite the historical richness of this framework and the empirical evidence supporting it, views of resilience from ecosystem science continue to pervade policy approaches. Santamaria (2014: online) writes for the U.K. Foreign and Commonwealth Office "The faster you are able to get back to "normal", the more resilient you are'. UNOCHA (2014: 1) declared 'When humanitarian relief is delivered quickly and critical needs are addressed immediately, communities are better able to focus on recovering from the initial shock and getting back to normal as quickly as possible'.

Addressing vulnerability and resilience should be about learning from history, past work, and wider contexts in order to break out of the normal trajectories leading to the normality of disasters. No assumption should be made that the present and future are the same as the past. Rather, it is about ensuring that history is considered and integrated into research, policy, and practice. Applying a long-term perspective, based on the literature analysing disaster risk reduction within development, seeks a 'normal' in which hazard effects, including those from climate change, are less detrimental and more advantageous for society. The 'normal' situation would aim for so-called hazards not being so hazardous and not being separated from other decisions, but instead being integrated into development processes.

\subsection{Placing climate change within wider contexts}

Given the difficulties which theories based in only climate change work pose for understanding and dealing with vulnerability and resilience, how should climate change be addressed? Learning from the history of the development and disaster risk reduction literature would mean applying the 'multiple exposure' perspective so that climate change sits as one hazard driver amongst many, contributing to the challenges and opportunities of the vulnerability and resilience processes (see also Gaillard 2010; Kelman et al. 2015; Mercer 2010). Approaches for climate change should be enacted by placing climate change within wider contexts so that the wider implications of interventions are considered.

For example, large hydroelectric dams might contribute to climate change mitigation through reducing dependence on fossil fuel-based energy. Large dams might also contribute to climate change adaptation by permitting a more stable water supply, irrespective of precipitation variations. As discussed earlier, large dams tend to increase flood risk over the long term. Many other development concerns of large dam projects have been identified including displacing populations, interfering with traditional livelihoods, and 
disrupting ecosystems (World Commission on Dams 2000). Climate change should not be tackled at the expense of other vulnerabilities and resiliences (see also Graham and Weiner 1995 for a risk perspective of trade-offs).

The subset within development work which is best suited for placing climate change mitigation is pollution prevention. Pollution prevention, having long been enshrined in some national laws and shown to be environmentally and economically effective (Royston 1980), refers to reducing and absorbing pollutants - the definition of climate change mitigation with respect to greenhouse gases as pollutants. Technologies and techniques advance each year and greenhouse gas-specific approaches are needed, yet the ethos and general implementation remain the same for all pollutants. Thus, climate change mitigation becomes a subset within pollution prevention.

The subset within development work that is best suited for placing climate change adaptation is disaster risk reduction (Kelman et al. 2015; Mercer 2010; Shaw et al. 2010a, b). As illustrated in the citations throughout this paper, disaster risk reduction has a long history of incorporating climate-related changes at all time and space scales and from multiple causes (see also Glantz 1994a, b). Climate change influences some hazards, augmenting or diminishing parameters, but it is not always the dominating driver. Disaster risk reduction, by definition, accounts for all drivers of hazards and vulnerabilities, so climate change is incorporated fully in disaster risk reduction by definition. As discussed throughout this chapter, disaster risk reduction, in turn, sits as one subset within development work.

This chapter has provided broad and deep background to understanding vulnerability and resilience beyond the narrow scope of single disciplines or topics. The importance of learning from literature which exists already, especially before climate change became a major topic, is demonstrated for ensuring that complete vulnerability and resilience processes are accounted for in order to tackle climate change in tandem with other contemporary development concerns. By learning from history while accepting changes since then, and by placing climate change within disaster risk reduction and development, the best of the past and present can be employed to create the future which society seeks.

Open Access This article is distributed under the terms of the Creative Commons Attribution 4.0 International License (http://creativecommons.org/licenses/by/4.0/), which permits unrestricted use, distribution, and reproduction in any medium, provided you give appropriate credit to the original author(s) and the source, provide a link to the Creative Commons license, and indicate if changes were made.

\section{References}

Adams J (1999) Risk. UCL Press, London

Adger WN (2006) Vulnerability. Glob Environ Change 16:268-281

Alexander DE (2013) Resilience and disaster risk reduction: an etymological journey. Nat Hazards Earth Syst Sci 13(11):2707-2716

Arnesen E (1994) Waterfront workers of New Orleans: race, class, and politics, 1863-1923. Illini Books, New York

Arrhenius S (1896) On the influence of carbonic acid in the air upon the temperature of the ground. Lond Edinb Dublin Philos Mag J Sci (Fifth Ser) 41(251):237-276

Ball N (1975) The myth of the natural disaster. Ecol 5(10):368-369

Bankoff G (2004) Time is of the essence: disasters, vulnerability and history. Int J Mass Emerg Disasters 22(3):23-42

Bankoff G, Frerks G, Hilhorst D (eds) (2004) Mapping vulnerability: disasters, development and people. Earthscan, London

Bosher L (ed) (2008) Hazards and the built environment. Taylor and Francis, London

Carr LJ (1932) Disaster and the sequence-pattern concept of social change. Am J Sociol 38(2):207-218 
Cashman A (2014) Water security and services in the Caribbean. Water 6(5):1187-1203

Coburn AW, Spence RJS (2002) Earthquake protection. John Wiley \& Sons, London

Comité d'Information Sahel (1975) Qui se nourrit de la famine en Afrique?. F. Maspero, Paris

Copans J (ed) (1975) Sécheresses et famines du Sahel. F. Maspero, Paris

Courtillot V, Fluteau F (2014) A review of the embedded time scales of flood basalt volcanism with special emphasis on dramatically short magmatic pulses. GSA Spec Pap 505:301-317

Crow SEM, Reeves OS, Schubert CA Sierra (2015) Optimization of method to quantify soil organic matter dynamics and carbon sequestration potential in volcanic ash soils. Biogeochemistry 123(1):27-47

Crush J (ed) (1995) Power of development. Routledge, London

Cuny FC (1991) Living with floods: alternatives for riverine flood mitigation. Land Use Policy 8(4):331-342

Day JW Jr, Boesch DF, Clairain EJ, Kemp GP, Laska SB, Mitsch WJ, Orth K, Mashriqui H, Reed DJ, Shabman L, Simenstad CA, Streever BJ, Twilley RR, Watson CC, Wells JT, Whigham DF (2007) Restoration of the Mississippi Delta: lessons from Hurricanes Katrina and Rita. Science 315:1679-1684

Enarson E, Morrow BH (eds) (1998) The gendered terrain of disaster: through women's eyes. Greenwood Publications, Connecticut

Etkin D (1999) Risk transference and related trends: driving forces towards more mega-disasters. Environ Hazards 1(2):69-75

Folke C (2006) Resilience: the emergence of a perspective for social-ecological systems analyses. Glob Environ Change 16:253-267

Fordham M (1998) Making women visible in disasters: problematising the private domain. Disasters 22:126-143

Fordham M (1999) Participatory planning for flood mitigation: models and approaches. Aust J Emerg Manag 13(4):27-34

Gaillard JC (2007) Resilience of traditional societies in facing natural hazards. Disaster Prevent Manag 16(4):522-544

Gaillard JC (2010) Vulnerability, capacity, and resilience: perspectives for climate and disaster risk reduction. J Int Dev 22(2):218-232

Gaillard JC, Clavé E, Vibert O, Azhari Dedi, Denain J-C, Efendi Y, Grancher D, Liamzon CC, Sari DR, Setiawan R (2008) Ethnic groups' response to the 26 December 2004 earthquake and tsunami in Aceh, Indonesia. Nat Hazards 47(1):17-38

Garcia-Acosta V (2004) La perspectiva histórica en la antropología del riesgo y del desastre: acercamientos metodológicos. Relaciones 97(25):125-142

Glantz MH (1994a) Creeping environmental problems. World I June:218-225

Glantz MH (1994b) Creeping environmental phenomena: are societies equipped to deal with them? In: Glantz MH (ed.) Creeping environmental phenomena and societal responses to them. Proceedings of workshop held 7-10 February 1994 in Boulder, Colorado. NCAR/ESIG, Boulder Colorado, pp 1-10

Glantz MH, Jamieson D (2000) Societal response to Hurricane Mitch and intra-versus intergenerational equity issues: whose norms should apply? Risk Anal 20:869-882

Global Network of Civil Society Organisations for Disaster Reduction (2009) 'Clouds but little rain...': views from the frontline-a local perspective of progress towards implementation of the hyogo framework for action. Global Network of Civil Society Organisations for Disaster Reduction, Teddington

Global Network of Civil Society Organisations for Disaster Reduction (2011) If we do not join hands...Global Network of Civil Society Organisations for disaster reduction views from the frontline local reports of progress on implementing the hyogo framework for action, with strategic recommendations for more effective implementation. Global Network of Civil Society Organisations for Disaster Reduction, Teddington

Gommes R, du Guerny J, Glantz MH, Hsu L-N (2004) Climate and HIV/AIDS: a hotspots analysis for early warning rapid response systems. UN Development Programme, Southeast Asia HIV and Development Programme, Bangkok

Graham JD, Weiner JB (eds) (1995) Risk vs. risk: trade-offs in protecting health and the environment. Harvard University Press, Cambridge

Henkel KE, Dovidio JF, Gaertner SL (2006) Institutional discrimination, individual racism, and Hurricane Katrina. Analyses of Social Issues and Public Policy 6(1):99-124

Hewitt K (ed) (1983) Interpretations of calamity from the viewpoint of human ecology. Allen \& Unwin, London

Hewitt K (1997) Regions of risk: a geographical introduction to disasters. Addison Wesley Longman, Essex

Hewitt K (2007) Preventable disasters: addressing social vulnerability, institutional risk, and civil ethics. Geogr Rundsch Int Ed 3(1):43-52 
Hills A (1998) Seduced by recovery: the consequences of misunderstanding disaster. J Conting Crisis Manag 6:162-170

Hoffman SM, Oliver-Smith A (eds) (2002) Catastrophe and culture: the anthropology of disaster. School of American Research Press/James Currey, Santa Fe/Oxford

IPCC (2012) IPCC special report on managing the risks of extreme events and disasters to advance climate change adaptation (SREX). IPCC (Intergovernmental Panel on Climate Change), Geneva

IPCC (2013-2014) IPCC fifth assessment report. IPCC (Intergovernmental Panel on Climate Change), Geneva

Jackson J (2001) Living with earthquakes: know your faults. J Earthq Eng 5(special issue 1):5-123

Janssen MA, Schoon ML, Ke W, Börner K (2006) Scholarly networks on resilience, vulnerability and adaptation within the human dimensions of global environmental change. Glob Environ Change 16:240-252

Kelman I, Lewis J, Gaillard JC, Mercer J (2011) Participatory action research for dealing with disasters on islands. Island Stud J 6(1):59-86

Kelman I, Gaillard JC, Mercer J (2015) Climate change's role in disaster risk reduction's future: beyond vulnerability and resilience. Int J Disaster Risk Sci 6(1):21-27

Kennedy J, Ashmore J, Babister E, Kelman I (2008) The meaning of 'build back better': evidence from posttsunami Aceh and Sri Lanka. J Conting Crisis Manag 16:24-36

King D (2004) Climate change science: adapt, mitigate, or ignore? Science 303:176-177

Laake K, Sverre JM (1996) Winter excess mortality: a comparison between Norway and England plus Wales. Age Ageing 25(5):343-348

Lavell A (2000) Desastres durante una década: lecciones y avances conceptuales y prácticos en América Latina (1990-1999). Anuario Política y Social de América Latina 3:1-34

Leichenko R, O’Brien K (2008) Environmental change and globalization: double exposures. Oxford University Press, Oxford

Lewis J (1979) The vulnerable state: an alternative view. In: Stephens L, Green SJ (eds) Disaster assistance: appraisal, reform and new approaches. New York University Press, New York, pp 104-129

Lewis J (1988) On the line: an open letter in response to "confronting natural disasters, an international decade for natural hazard reduction". Nat Hazards Observ XII(4):4

Lewis J (1989) Sea-level rise: some implications for Tuvalu. Ambio 18(8):458-459

Lewis J (1999) Development in disaster-prone places: studies of vulnerability. Intermediate Technology Publications, London

Lewis J (2003) Housing construction in earthquake-prone places: perspectives, priorities and projections for development. Aust J Emerg Manag 18:35-44

Lewis J, Kelman I (2010) Places, people and perpetuity: community capacities in ecologies of catastrophe. ACME Int E J Crit Geogr 9(2):191-220

Liverman DM (1990) Vulnerability to global environmental change. In: Kasperson RE, Dow DG, Kasperson JX (eds) Understanding global environmental change: the contributions of risk analysis and management. Clark University, Worchester, pp 27-44

Manyena SB (2006) The concept of resilience revisited. Disasters 30(4):433-450

Manyena SB, Gordon S (2015) Bridging the concepts of resilience, fragility and stabilisation. Disaster Prevent Manag 24(1):38-52

Manyena SB, O’Brien G, O'Keefe P, Rose J (2011) Disaster resilience: a bounce back or bounce forward ability? Local Environ 16(5):417-424

Martin PS (2005) Twilight of the mammoths: ice age extinctions and the rewilding of America. University of California Press, London

Maskrey A (1989) Disaster mitigation: a community based approach, development guidelines no 3. Oxfam, Oxford

McAdoo B, Dengler L, Prasetya G, Titov V (2006) Smong: how an oral history saved thousands on Indonesia's Simeulue Island during the December 2004 and March 2005 tsunamis. Earthq Spec 22(S3):S661-S669

Mercer J (2010) Disaster risk reduction or climate change adaptation. Are we reinventing the wheel? J Int Dev 22(2):247-264

Mileti D, 136 contributing authors (1999) Disasters by design: a reassessment of natural hazards in the United States. Joseph Henry Press, Washington

MIT (Massachusetts Institute of Technology) (1970) Man's impact on the global environment. Report of the Study of Critical Environmental Problems (SCEP). MIT Press, Cambridge

MIT (Massachusetts Institute of Technology) (1971) Inadvertent climate modification. Report of the Study of Man's Impact on Climate (SMIC). MIT Press, Cambridge 
Mitrovic VL (2015) Resilience: detecting vulnerability in marginal groups. Disaster Prevent Manag 24(2):185-200

Murphy MP Jr, Ricks A (2013) Beyond shelter: architecture and human dignity. J Archit 18(1):111-114

ODI (2015) Unlocking the 'triple dividend' of resilience: why investing in disaster risk management pays off. ODI (Overseas Development Institute), London

O'Keefe P, Westgate K, Wisner B (1976) Taking the naturalness out of natural disasters. Nature 260:566-567

Oliver-Smith T (1979) Post disaster consensus and conflict in a traditional society: the 1970 Avalanche of Yungay, Peru. Mass Emerg 4:39-52

Oliver-Smith T (1986) The Martyred City: death and rebirth in the Andes. University of New Mexico Press, Albuquerque

Palmer DM, Barthelmy S, Gehrels N, Kippen RM, Cayton T, Kouveliotou C, Eichler D, Wijers RAMJ, Woods PM, Granot J, Lyubarsky YE, Ramirez-Ruiz E, Barbier L, Chester M, Cummings J, Fenimore EE, Finger MH, Gaensler BM, Hullinger D, Krimm H, Markwardt CB, Nousek JA, Parsons A, Patel S, Sakamoto T, Sato G, Suzuki M, Tueller J (2005) A giant $\gamma$-ray flare from the magnetar SGR 180622. Nature 434:1107-1109

Papathoma-Koehle M, Kappes M, Keiler M, Glade T (2011) Physical vulnerability assessment for alpine hazards: state of the art and future needs. Nat Hazards 58(2):645-681

Paton D, Johnston DM (2001) Disasters and communities: vulnerability, resilience and preparedness. Disaster Prevent Manag 10(4):270-277

Paton D, Johnston DM (2006) Disaster resilience: an integrated approach. Charles C Thomas, Springfield

Perna D, Barucci MA, Drube L, Falke A, Fulchignoni M, Harris AW, Harris AW, Kanuchova Z (2015) A global response roadmap to the asteroid impact threat: the NEOShield perspective. Planet Space Sci 118:311-317

Prince SH (1920) Catastrophe and social change. Doctoral Dissertation, Columbia University, New York

Pugh J (2014) Resilience, complexity and post-liberalism. Area 46(3):313-319

Revelle R, Suess HE (1957) Carbon dioxide exchange between atmosphere and ocean and the question of an increase of atmospheric CO, during the past decades. Tellus 9(1):18-27

Richman RC, Pressnail KD, Kirsh AM (2007) Exterior basement insulation: further proof of the need to build better now. Paper presented at the 11th canadian conference on building science and technology, Banff, Alberta, 21-23 March 2007

Royston MG (1980) Making pollution prevention pay. Harvard Bus Rev 58(6):6-22

Santamaria C (2014) The UK harnessing science to "bounce back". Blog on 31st March 2014 Houston, USA. http://blogs.fco.gov.uk/catherinesantamaria/2014/03/31/the-uk-harnessing-science-to-bounceback

Shaw R, Pulhin JM, Pereira JJ (2010a) Climate change adaptation and disaster risk reduction: issues and challenges. Bingley, Emerald

Shaw R, Pulhin JM, Pereira JJ (2010b) Climate change adaptation and disaster risk reduction: an Asian perspective. Bingley, Emerald

Spence R (2004) Risk and regulation: can improved government action reduce the impacts of natural disasters? Build Res Inf 32(5):391-402

Steinberg T (2000) Acts of god: the unnatural history of natural disaster in America. Oxford University Press, New York

Sudmeier-Rieux KI (2014) Resilience-an emerging paradigm of danger or of hope? Disaster Prevent Manag 23(1):67-80

Tapsell SM, Penning-Rowsell EC, Tunstall SM, Wilson TL (2002) Vulnerability to flooding: health and social dimensions. Philos Trans R Soc Lond A 360(1796):1511-1525

Timmerman P (1981) Vulnerability, resilience and the collapse of society: a review of models and possible climatic applications. Environmental monograph 1. Institute for Environmental Studies, University of Toronto, Toronto

Tiranti D (1977) The un-natural disasters. New Int 53:5-6

Tobin GA (1999) Sustainability and community resilience: the Holy Grail of hazards planning? Environ Hazards 1:13-25

Torry WI (1979) Hazards, hazes and holes: a critique of The Environment as Hazard and general reflections on disaster research. Can Geogr 23(4):368-383

Townsend CR, Begon M, Harper JL (2003) Essentials of ecology. Blackwell Publishing, Oxford

Turcios AMI (2001) Central America: A region with multiple threats and high vulnerability? Norwegian Church aid occasional paper series, number 5/2001 
UNISDR (2002) Disaster reduction for sustainable mountain development: 2002 United Nations world disaster reduction campaign. UNISDR (United Nations International Strategy for Disaster Reduction), Geneva

UNISDR (2015) Terminology. http://www.unisdr.org/we/inform/terminology

UNOCHA (2014) OCHA Statement. In: 6th Asian ministerial conference on disaster risk reduction, Bangkok, 26 June 2014. UNOCHA (United Nations Office for the Coordination of Humanitarian Affairs), New York

Waddell E (1977) The hazards of scientism: a review article. Hum Ecol 5(1):69-76

Weart S (2008) The discovery of global warming. Harvard University Press, Harvard

Weichselgartner J (2001) Disaster mitigation: the concept of vulnerability revisited. Disaster Prevent Manag 10(2):85-94

White GF (1936) The limit of economic justification for flood protection. J Land Pub Util Econ 12:133-148

White GF (1937) Economic justification for flood protection. Civ Eng 7(5):345-348

Wisner B, Blaikie P, Cannon T, Davis I (2004) At risk: natural hazards, people's vulnerability and disasters, 2nd edn. Routledge, London

Wohl E (ed) (2000) Inland flood hazards: human, riparian, and aquatic communities. Cambridge University Press, Cambridge

World Commission on Dams (2000) Dams and development, a new framework for decision-making. Earthscan, London

Zaman MQ (1993) Rivers of life: living with floods in Bangladesh. Asian Surv 33(10):985-996 